\title{
TÉRDPROTÉZIS GEOMETRIA FEJLESZTÉSE ÉS VIZSGÁLATA
}

\section{DEVELOPMENT AND EXAMINATION OF A KNEE PROSTHESIS GEOMETRY}

\author{
Balassa Gábor Péter
}

Szent István Egyetem, Gépészmérnöki Kar, Mechanikai és Géptani Intézet, Mechanika és Müszaki Ábrázolás Tanszék, Gödöllő, Magyarország, balassa.gabor.peter@hallgato.szie.hu

\begin{abstract}
The necessity of the knee prosthesis confirmed by the large increase in the number of patients suffering from arthrosis, which is a present-day disease. Despite of the need doesn't exist optimal knee prosthesis. Nowadays the development of the knee prostheses are takes place. It is very difficult to define the geometry with traditional methods, because the movement conditions that created by the prostheses should be similar of the movements of the human knee. During previous researches the biomechanical research team of the Szent Istvan University is defined with experimental measurements the healthy human knee joint movement. In this paper I would like to introduce a method of prosthesis geometry development. As a result a knee prosthesis geometry was created which is approaching the movement form of the real human knee joint.
\end{abstract}

Keywords: knee, kinematics, prosthesis, experimental apparatus.

\section{Összefoglalás}

A térdprotézis szükségességét a napjaink népbetegségének számító arthrózisban szenvedő betegek számának nagymértékü növekedése igazolja. Az igény ellenére jelenleg nem létezik optimális térdprotézis. A térdprotézisek fejlesztése napjainkban is zajlik. Geometriáját igen nehézkes a hagyományos módszerekkel meghatározni, mivel a protézisek által létrehozott mozgásviszonyoknak hasonlítaniuk kell az emberi térd által megvalósított mozgásokra. A Szent István Egyetem Biomechanikai Kutatócsoportja korábbi munkái során kísérleti mérések segítségével meghatározta az egészséges emberi térdízület mozgását. Jelen dolgozatban azt a protézis geometria fejlesztési módszert kívánom bemutatni, amely eredményeként egy olyan térdprotézis jött létre, amely a valódi emberi térdízületi mozgásformát kiválóan közelíti.

Kulcsszavak: térd, kinematika, protézis, kísérleti vizsgálóberendezés.

\section{Bevezetés, célkitűzés}

Napjaink egyik jelentős ortopédiai problémája a térdízületben keletkező degeneratív kopás (arthrózis) megfelelő kezelése A megfelelő kezelési eljárás a teljes felszínpótló térdprotézis beültetése. Sajnos jelenleg nem áll rendelkezésre olyan térdprotézis, amely hosszú távon a páciens életminőségét javítaná, mivel megváltoztatják az ízület eredeti kinematikáját [1]. A térdprotéziseknek sokféle követelménynek kellene megfelelniük, amelyek közül a speciális mozgásviszonyok mostanáig sincsenek teljesítve.
Jelen tanulmány célja annak a módszernek a bemutatása, amely egy egyedi térdprotézis geometria fejlesztésére került kidolgozásra.

A térdprotézis által létrehozott mozgást a térdízületre jellemző, egymással kapcsolódó többször görbült felületek egymáshoz viszonyított elmozdulása biztosítja. A térdprotézis geometriai fejlesztéséhez és vizsgálatához kiindulásképp egy használt protézis geometriáját módosítom. A tervezéshez parametrizált 3D modellezést és felületmodellezést alkalmazok.

Az így létrejött modellt CNC marási technológiával legyártom, majd a Szent István Egyetem 
Biomechanikai Kutatócsoportjának protézisminősítő berendezésével minősítem. A minősítés alapja a térdprotézis által létrehozott mozgás és az ugyanezen a berendezésen mért emberi térdízület mozgásviszonyainak a különbsége.

Az eljárás célja, egy olyan térdprotézis létrehozása, amely az emberi térdízület által elvárt mozgást valósítja meg.

\subsection{A térdmozgások és a célfüggvény}

A térdízület az emberi ízületek közül a legbonyolultabb. A térdízület forgócsukló ízület, 6 szabadságfokkal rendelkezik [2], mozgáslehetőségeit az 1. ábra mutatja.

Kutatómunkám során a térdízület mozgásformái közül a flexió és a rotáció egymáshoz viszonyított értékei fontosak. A rotációs mozgást két részre lehet bontani, az akaratlagos, és az önkéntelen rotációra. Az önkéntelen rotáció nem izomműködés eredménye [3]. A lábszár hajlítása kismértékű befelé forgatással kezdődik, és egyértelműen a lábszár nyújtása is kifelé forgatással kezdődik. Az akaratlagos rotáció a behajlított térdízület sajátossága.

A természetes térd combcsonti (femorális) komponensén a középvonaltól kifelé (laterális) és középvonaltól befelé (mediális) ízületi felszínek aszszimetriája miatt be- és kihajlítás során a laterális felszín nagyobb utat jár be, mint a mediális felszín. Kutatócsoportunk és a velünk kapcsolatban levő orvos-kutatócsoportok hipotézise szerint is
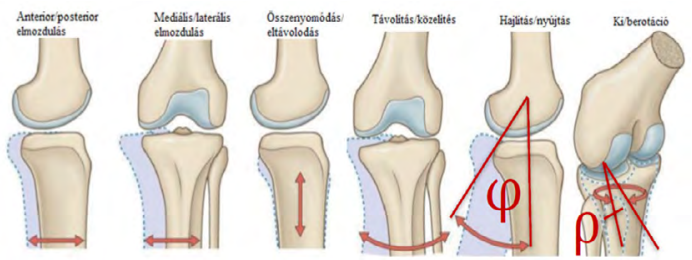

1. ábra. A térdízület mozgáslehetőségei [4]

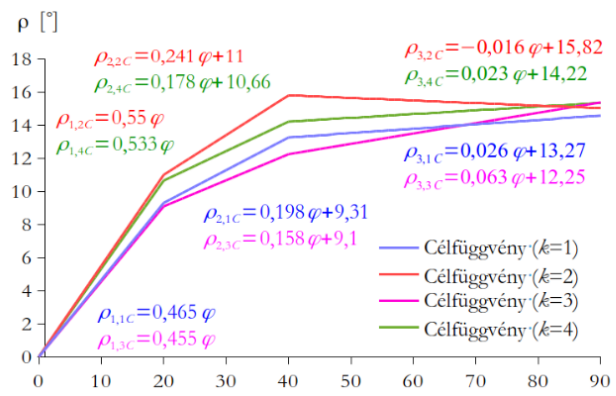

2. ábra. Az egészséges emberi térdízület mozgását leíró célfüggvény [6,7] ez a geometriai sajátosság okozza a sípcsont elfordulását, a kifelé és befelé rotációt.

A Szent István Egyetem Biomechanikai Kutatócsoportja munkájuk során meghatározta az egészséges emberi térdízület kinematikáját leíró mozgásfüggvényt. Ehhez cadaver térdeken végzett vizsgálatokat egy kísérleti vizsgálóberendezés [5] segítségével.

E célfüggény (2. ábra) eredménye, mint bemeneti paraméter szolgál a térdprotézis geometria fejlesztéshez. Mivel a rotációs mozgás két részre bontható, valamit a két jól elkülönülő mozgásforma között egy átmeneti szakasz is található, így lehetőség van a mozgást trilineáris függvénnyel közelíteni.

\section{Anyag és módszer}

A következőkben bemutatom a Kutatócsoportunk által fejlesztett térdprotézis vizsgáló berendezést. A cadaver térdek vizsgálatához kifejlesztett berendezés nem volt alkalmas térdprotézisek vizsgálatára, így vált szükségessé egy protézis vizsgáló rendszer kialakítása.

\subsection{A térdprotézis vizsgáló berendezés}

A készülék fő egységei a protézisvizsgáló rész illetve a protézis felületek egymáson való legördítését és mozgatását végző mozgató mechanizmus. A mozgatást léptetőmotor biztosítja, mindeközben a berendezésben inkrementális forgásjeladók rögzítik a hajlítási szögértékeket és a hozzájuk tartozó lábszárcsonti elfordulás értékeit. A mérőberendezés biztosítja a 6 szabadságfokú mozgást kétoldali vezetőpályájával. A mozgó tengely csupán a szükséges behajlítást végzi el a léptetőmotor segítségével, a tibiális komponenst szabadon engedi mozogni. A szükséges érintkezés fenntartásához a négyfejü combizom gumiizom modellként került beépítésre.

Az erőmérő cellával mérhető a behajlítás során keletkező erő. A mérések során mindig $120 \mathrm{~N}$ előterheléssel pozícionálom a protézis komponenseket egymáshoz. Az erőmérő cellával mérhető erőt a behajlítás tartományában monitoroztam Spider 8 mérőadatgyüjtő rendszerrel. A 3. ábrán látható a protézis vizsgáló berendezés, piros színnel jelölve a térdprotézis combcsonti komponense, illetve kékkel a lábszárcsonti komponens.

A mérési folyamatot leíró főbb paraméterek:

- előterhelés: $120 \mathrm{~N}$;

- mozgástartomány: $0^{\circ}-120^{\circ}$;

-forgás-jeladók felbontása: $0,18^{\circ}$. 


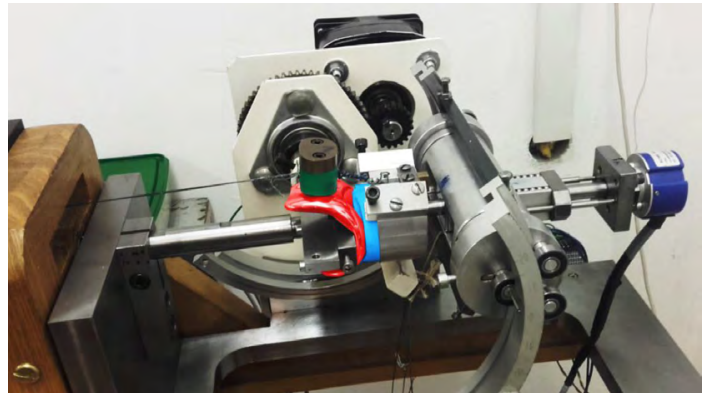

3. ábra. A térdprotézisek kinematikai vizsgálatához kifejlesztett kísérleti berendezés

\subsection{A térdprotézis geometria fejlesztési módszere}

A saját térdprotézis geometria fejlesztése során kiindulási paraméterként egy napjainkban is beépítésre kerülő, kereskedelmi forgalomban kapható térdprotézist választok.

A fejlesztés során a combcsonti komponenst állandónak tekintem, és ehhez készítek egy új lábszárcsonti komponenst. Azért alkalmazom ezt a módszert, ugyanis a tapasztalatok szerint a combcsonti komponens geometriája elfogadott, jellemzően a lábszárcsonti komponens geometriája okozza a problémát, így én is ezt fejlesztem. A 4. ábrán látható a protézis két komponense.

A geometriai fejlesztés során azt a hipotézist alkalmaztam, miszerint egy átlagosnak tekinthető combcsonti protézis komponenshez megfelelő fejlesztési eljárás segítségével tervezhető olyan lábszárcsonti komponens, amelyek együttesen irányított mozgást hoznak létre.

A femorális és tibiális komponenseket összekényszerezem a modelltérben a vizsgálóberendezés modellje által megvalósított körülmények szerint, majd a tibiális komponenst végigvezetem a femorális komponensen a megvalósítandó függvénykapcsolatok szerint. A geometria fejlesztés bemeneti paramétere a 2 . ábrán látható $\mathrm{k}=1$ célfüggvény volt. Végezetül a felületeket kivontam egymásból az 5 . ábrán látható módon $10^{\circ}$-onként egymásba forgatva.
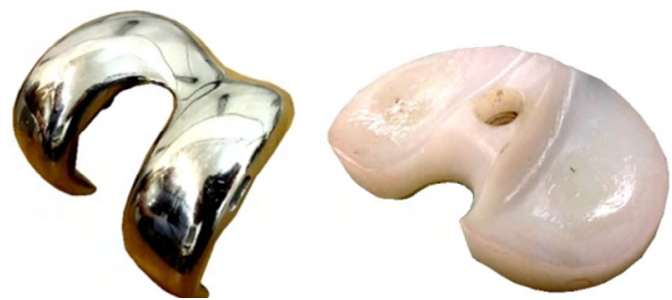

4. ábra. Kereskedelmi forgalomban kapható térdprotézis

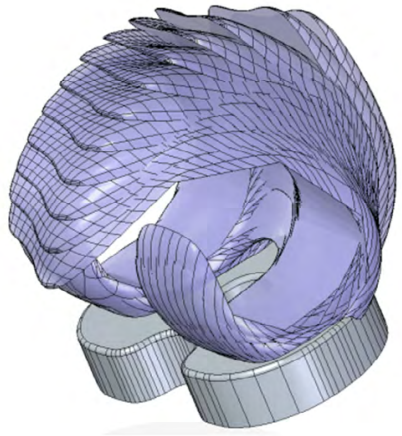

5. ábra. A protézis geometriák egymásba forgatása

\subsection{A legyártott térdprotézis}

A fent ismertetett módszerrel kifejlesztett 3 dimenziós CAD modellből a térdprotézis tibiális komponensét CNC marógépen állítottam elő (6 ábra).

Így a protézis azonos technológiával készült, mint a napjainkban is beépítésre kerülő térdimplantátumok. A lábszárcsonti térdprotézis komponens anyagául UMHW-PE polimert választottam. Ezt alkalmazzák a valódi térdprotézisek esetében is, biztosítva a kellő mechanikai ellenálló képességet.

\section{Eredmények és összefoglalás}

Az ily módon előállított térdprotézist kísérleti méréssorozatnak vetettem alá a 3 . ábrán bemutatott térdprotézis vizsgáló berendezés segítségével. A mérések előtt a vizsgálóberendezés ellenőrző kalibrálását hajtottam végre, majd a 4. ábrán látható használt térdprotézisen végeztem mérést.

Jól látható, hogy a kereskedelmi forgalomban kapható térdprotézisen nem valósul meg rotáció. A vizsgált tibiális komponens felületét tekintve szimmetrikus kialakítású volt.

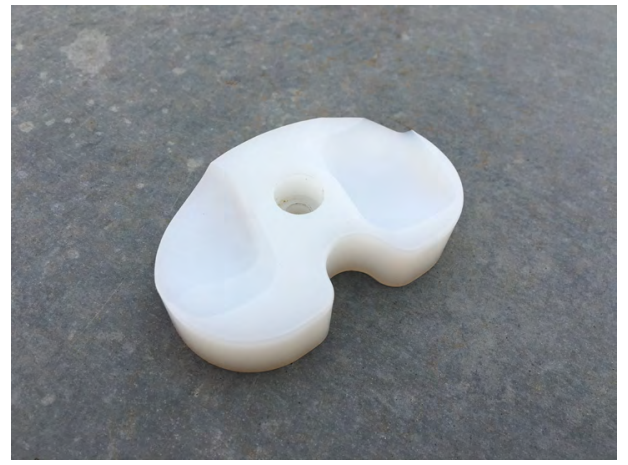

6. ábra. CNC marással előállított lábszárcsonti térdprotézis komponens 


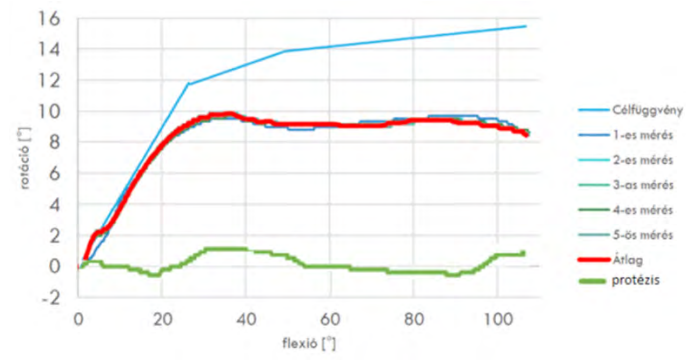

7. ábra. Kísérleti mérési eredmények

Kísérleti méréseimet ötszörös ismétléssel végeztem. A kifejlesztett geometria vizsgálatát a cadaver térdek alapján meghatározott célfüggvényhez képest minősítem. A mérések során a protézis komponensek alaphelyzetbe állítása nem volt szükséges, mivel a geometria visszatért a kiindulási pozíciójába. Így hajlítás és nyújtás ciklusokat is vizsgálhattam. Ez a jelenség korábbi munkáink során nem volt tapasztalható [8].

\section{Következtetések}

Jelen dolgozat egy hipotézist mutat be a térdprotézis geometriák kinematikai alapú fejlesztésére vonatkozóan. A két protézis komponenst egymáshoz kényszerezzük olyan módon, ahogyan az a célfüggvény szerint valóban mozogna. Majd az így kialakuló felületmetszeteket egymásból kivonjuk. A létrejött felületek között nem alakul ki alakzáró kapcsolat és képesek egymáson elcsúszni, mégis képesek közelíteni a célfüggvényt. Kutatásunk eredményének jelentősége abban rejlik, hogy a napjainkban beépítésre kerülő protézis geometriák rendkívül csekély rotációt hoznak létre. Kutatócsoportunk több kísérleti protézis geometriai fejlesztési eljárást is kidolgozott [8], de a jelen tanulmányban bemutatott eredmény jellegében tekintve közelíti eddig legjobban a valódi térdmozgást.

Továbblépési lehetőségként a geometriát meg kell vizsgálni kopásállóság szempontjából is. Amennyiben e szempontból is megfelel, úgy a gyakorlati alkalmazására is lehetőség nyílik.

\section{Szakirodalmi hivatkozások:}

[1] Ostermeier S., Hurschler C., Stukenborg-Colsman C.: Quadriceps function after TKA - an in vitro study in a knee kinematic simulator. Clinical Biomechanics 19. (2004) 270-276.

[2] Grood E. S., Suntay W. J.: A joint coordinate system for the clinical description of three-dimensional motions: application to the knee. Journal of Biomechanical Engineering. 105/2. (1983) 136-144. https://doi.org/10.1115/1.3138397

[3] Miltényi M.: A sportmozgások anatómiai alapjai. Budapest, 1980. 164-185.

[4] Standring S.: Gray's Anathomy, The anatomical basis of clinical practice. Spain, Churchill-Livingstone-Elsevier Press, $40^{\text {th }}$ Edition, 2008. 43004354.

[5] Szakál Z.: Mérőberendezés térdízület mozgásvizsgálatához. GÉP 57/1. (2006) 37-40.

[6] Katona G., Csizmadia M. B., Andrónyi K.: Determination of reference function to knee prosthesis rating. Biomechanica Hungarica 6/1. (2013) 293-301.

[7] Katona G., Csizmadia M. B., Balassa G.: $A z$ egészséges emberi térdízület kinematikáját leíró „célfüggvény” létrehozása. Biomechanica Hungarica 10/1. (2017) 9-21.

[8] Kopcsányi G., Balassa G.P., Oldal I.: Térdprotézis kinematikájának javítása evolúciós algoritmus alkalmazásával. Biomechanica Hungarica 10/1. (2017) 65-73. 